\title{
Persepsi Mahasiswa Terhadap Sistem Unggah Mandiri dan Akses ETD Repositori di Perpustakaan UGM Yogyakarta
}

\author{
Machsun Rifauddin \\ Pascasarjana, UIN Sunan Kalijaga Yogyakarta \\ machsunr@yahoo.com \\ Arfin Nurma Halida \\ Institut Agama Islam Negeri Tulungagung \\ arfin.nurma.halida19@gmail.com
}

\begin{abstract}
Repositories in Higher Education have a very important role. In addition to storing scientific work produced by students, the repository also serves to improve the ranking of Webometrics in order to realize World Class University. Therefore the policy of repository development must be done properly by considering the aspect of its users. This study aims to explain the students' perceptions of independent upload system and ETD access repository in UGM library. This research uses descriptive qualitative approach with data retrieval technique using interview and completed with document. Data analysis is done by data reduction, data display and conclusion drawing. The results show that self-propagation policies and ETD access repository are considered to be very precise according to the perception of users, since the need for electronic information is increasing. The policy must be done to create open access in order to realize the excellent service in the library. Independent upload systems and ETD access repositories can improve their evectivity and efficiency as students can upload and access their final assignments from anywhere and anytime. It also provides security and convenience for students because the files that have been uploaded are stored in the system and can be downloaded or requested to the library whenever needed.
\end{abstract}

Keywords: Academic library, perception; independent upload; repository; ETD. 


\begin{abstract}
Abstrak
Repositori di Perguruan Tinggi memiliki peran yang sangat penting. Selain untuk menyimpan karya ilmiah yang dihasilkan oleh mahasiswa, repositori juga berfungsi untuk meningkatkan peringkat Webometrics dalam rangka mewujudkan World Class University. Oleh karena itu kebijakan pengembangan repositori harus dilakukan secara tepat dengan mempertimbangkan aspek penggunanya. Penelitian ini bertujuan untuk menjelaskan persepsi mahasiswa terhadap sistem unggah mandiri dan akses ETD repositori di perpustakaan UGM. Penelitian ini menggunakan pendekatan kualitatif deskriptif dengan teknik pengambilan data menggunakan wawancara dan dilengkapi dengan dokumen. Analisis data dilakukan dengan cara reduksi data, penyajian data dan penarikan simpulan. Hasil penelitian menjukkan bahwa kebijakan unggah mandiri dan akses ETD repositori dinilai sangat tepat menurut persepsi pemustaka, mengingat kebutuhan terhadap informasi elektronik saat ini semakin meningkat. Kebijakan tersebut wajib dilakukan untuk menciptakan open acces dalam rangka mewujudkan pelayanan prima di perpustakaan. Sistem unggah mandiri dan akses ETD repositori dapat meningkatkan evektifitas dan efisiensi karena mahasiswa dapat men-unggah dan mengakses tugas akhir mereka dari mana saja dan kapan saja. Selain itu juga memberikan keamanan dan kenyamanan bagi mahasiswa karena file yang telah di-unggah tersimpan didalam sistem dan dapat di-download atau diminta ke perpustakaan ketika sewaktu-waktu dibutuhkan.
\end{abstract}

Kata Kunci: Perpustakaan akademik; persepsi; unggah mandiri; repositori; ETD.

\title{
Pendahuluan
}

Perkembangan informasi semakin pesat dan beragam di era keterbukaan informasi. Era ini ditandai dengan kemudahan akses pengiriman dan pemerolehan informasi. Perpustakaan sebagai salah satu lembaga pengelola informasi diharapkan dapat merespon perubahan perilaku pencarian informasi pemustakanya. Perpustakaan harus lebih terbuka, yaitu memberikan akses seluas-luasnya kepada pemustaka untuk memanfaatkan koleksi yang dimilikinya. Perpustakaan merupakan institusi pengelola koleksi karya tulis, karya cetak, dan/atau karya rekam secara profesional dengan sistem yang baku guna memenuhi kebutuhan pendidikan, penelitian, 
pelestarian, informasi, dan rekreasi para pemustaka. ${ }^{1}$ Tugas perpustakaan selain mengembangkan koleksi juga memberikan kemudahan akses terhadap koleksi yang dimilikinya untuk mewujudkan fungsi perpustakaan sebagai penyedia sumber informasi bagi pemustaka. Salah satu jenis perpustakaan yang dituntut untuk terus mengembangkan koleksi adalah Perpustakaan Perguruan Tinggi. Perpustakaan Perguruan Tinggi adalah perpustakaan yang melayani seluruh kebutuhan civitas akademika di Perguruan Tinggi tertentu (akademi, universitas, institut, sekolah tinggi, politeknik) yang bertujuan untuk menunjang pencapaian tujuan Perguruan Tinggi yang bersangkutan dalam melaksanakan Tri Dharma Perguruan Tinggi. ${ }^{2}$ Perpustakaan perpustakaan sering disebut dengan jantungnya Perguruan Tinggi karena keberadaannya yang sangat vital.

Sebagai lembaga pengelola informasi, perpustakaan wajib melestarikan tempat penyimpanan informasi dan juga memperhatikan repositori untuk memperkaya khazanah pengetahuan yang bermanfaat bagi seluruh civitas akademika sebuah Perguruan Tinggi khususnya, dan umumnya bagi siapa saja yang mencari pengetahuan. Perpustakaan Perguruan Tinggi adalah salah satu perpustakaan yang menerapkan teknologi informasi dalam memenuhi kebutuhan informasi, salah satu informasi yang ada di perpustakaan adalah repositori. Repositori di Perguruan Tinggi memiliki peran yang sangat penting. Institusional Repository merupakan salah media untuk mempublikasikan secara online karya-karya khas Universitas yang dihasilkan oleh siviitas akademika. ${ }^{3}$ Seiring bertambahnya koleksi cetak di perpustakaan akan mengakibatkan krisis tempat penyimpanan dan akan menyita banyak tenaga dan biaya untuk mengelolanya. Oleh karena itu sistem repositori koleksi digital di perpustakaan harus dimaksimalkan.

\footnotetext{
${ }^{1}$ Perpustakaan Nasional Republik Indonesia. Undang-Undang Nomor 43 Tahun 2007 Tentang Perpustakaan, http://dev.perpusnas.go.id/law/undang-undang-nomor-43-tahun-2007-tentangperpustakaan/, diakses tanggal 25 Oktober 2017.

${ }^{2}$ F. Rahayuningsih, Pengelolaan Perpustakaan, Yogyakarta: Graha Ilmu, 2007, 7.

${ }^{3}$ Ummi Rodliyah, Penggunaan Aplikasi E-Prints untuk Pengembangan Intitutional Repository dan Pengaruhnya terhadap Peringkat Webometrics Perguruan Tinggi di Indonesia, Libraria, Vol. 4, No. 1, Juni 2017, 223-248.
} 
Beberapa Perpustakaan Perguruan Tinggi saat ini telah memiliki kebijakan sendiri dalam pengembangan repositori, salah satunya adalah Perpustakaan UGM yang telah mengeluarkan kebijakan menggunakan sistem unggah mandiri untuk penyerahan tugas akhir mahasiswa. Penggunaan sistem ini sebagai upaya untuk memudahkan proses penyerahan tugas akhir (skripsi, tesis dan disertasi) mahasiswa UGM sebagai salah satu syarat untuk mengikuti wisuda. File tugas akhir yang telah diunggah dapat diakses melalui sistem ETD (Elektronik Theses \& Dissertations), yaitu layanan repositori perpustakaan yang menyediakan koleksi tugas akhir (dalam bentuk file) yang dihasilkan oleh mahasiswa UGM. Sistem unggah mandiri dan ETD merupakan terobosan baru dalam pengembangan sistem repositori di Perpustakaan Perguruan Tinggi, dimana penyerahan tugas akhir yang sebelumnya hanya dalam bentuk cetak dan soft copy yang di-burning kedalam CD (Compact Disc). Karena sistem ini tergolong baru maka terdapat beberapa mahasiswa yang belum mengerti dan memahami kebijakan pemanfaatan sistem tersebut. Penelitian ini bertujuan untuk menjelaskan bagaimana bentuk penyerahan karya akhir mahasiswa, meta data yang dimasukkan atau di-input, komponen apa saja yang dapat diakses serta persepsi mahasiswa terhadap sistem unggah mandiri dan akses ETD repositori di Perpustakaan UGM.

Penelitian ini menggunakan pendekatan kualitatif deskriptif dengan jenis penelitian lapangan (field researce). Subjek penelitian ini adalah pemustaka di Perpustakaan UGM. Teknik pengambilan data menggunakan wawancara (interview) dilengkapi dengan sejumlah dokumen. Analisis data dilakukan dengan cara 1). Reduksi data (data reduction) yaitu, peneliti melakukan pemilihan data-data dari semua informasi yang didapat baik dari wawancara, hasil pengamatan dan dokumen, kemudian secara kemudian diklasifikasi. 2). Penyajian data (data display), yaitu, mendeskripsikan informasi dari data-data yang telah diklasifikasi sebelumnya. 3). Penarikan simpulan (conclusion drawing and verification) yaitu, mengkaji ulang data yang telah disimpulkan sebelumnya dengan cara pengecekkan dan pencocokkan, kemudian dilakukan penarikan kesimpulan. Sedangkan 
pegecekan keabsahan data dilakukan dengan metode triangulasi. Hasil penelitian ini dapat dijadikan rujukan untuk menambah khazanah keilmuan dibidang perpustakaan dan informasi, dan sebagai bahan pertimbangan bagi pengelola perpustakaan dalam pengembangan repositori di Perpustakaan Perguruan Tinggi.

\section{Pembahasan}

\section{Repositori Perpustakaan Perguruan Tinggi}

Institutional repository (IR) mulai dikenal dan berkembang seiring munculnya istilah perpustakaan digital pada awal tahun 1990-an yang merujuk pada kegiatan untuk menghimpun dan melestarikan koleksi digital dari hasil karya intelektual. Secara sederhana repositori dapat diartikan sebagai tempat penyimpanan, dan dalam konteks perpustakaan repositori berarti tempat dimana koleksi disimpan dan dimanfaatkan. Repositori merupakan hasil perkembangan dari teknologi informasi di perpustakaan dan identik dengan tempat penyimpanan koleksi-koleksi digital. Institutional Repository (IR) sering sering kali disebut dengan Gray Literature (literature kelabu) atau sebelumnya juga diklasifikasikan sebagai koleksi lokal konten. ${ }^{4}$ Menurut Pendit Institutional repository merujuk ke sebuah kegiatan menghimpun dan melestarikan koleksi digital yang merupakan hasil karya intelektual dari sebuah komunitas tertentu. ${ }^{5}$

Institutional repository juga diartikan sebagai layanan digital yang dirancang untuk mengumpulkan, melestarikan, dan menyebarluaskan seluruh aset intelektual Universitas agar dapat diakses secara terbuka oleh para ilmuan (scholars). ${ }^{6}$ Pendapat lain menyatakan bahwa repositori berarti suatu tempat untuk menyimpan dan melestrarikan informasi digital yang didistribusikan dalam jaringan komputer untuk digunakan kembali. ${ }^{7}$ Repositori pada intinya

\footnotetext{
${ }^{4}$ Ummi Rodliyah, Penggunaan Aplikasi E-Prints, 226.

${ }^{5}$ Putu Laxman Pendit, Perpustakaan Digital dari A sampai Z. Jakarta: Citra Karyakarsa Mandiri, 2008, 137

${ }^{6}$ Ulpah Andayani, Pengolahan Konten Repositori di Pusat Perpustakaan UIN Syarif Hidayatullah Jakarta, Jurnal Al-Maktabah, Vol. 14, 2015, 46-55.

${ }^{7}$ Wiyarsih, Pemanfaatan Koleksi Repository Perpustakaan Fakultas MIPA UGM
} 
mengacu pada penyimpanan dan preservasi informasi digital. Penyimpanan informasi dilakukan didalam sebuah server komputer, dikelola sedemikian rupa, diorganisasikan dan selanjutnya dilayankan dalam bentuk elektronik digitial. Proses membangun repositori di perpustakaan memerlukan banyak persiapan, mulai dari masalah sarana, sumber daya manusia, dan pastinya anggaran. Oleh sebab itu, pembangunan repositori harus dapat dukungan dan kerjasama dari berbagai pihak.

\section{Urgensi Repositori di Perpustakaan Perguruan Tinggi}

Perpustakaan Perguruan Tinggi merupakan suatu unit pelaksana teknis (UPT) yang bersama-sama dengan unit lain turut melaksanakan Tri Dharma Perguruan Tinggi dengan cara memilih, menghimpun, mengolah, merawat, dan melayankan sumber informasi kepada lembaga induknya pada khususnya dan masyarakat akademis pada umumnya. ${ }^{8}$ Perpustakaan Perguruan Tinggi memiliki fungsi khusus yaitu sebagai tempat penyedia informasi bagi seluruh civitas akademika di Perguruan Tinggi. Oleh karena itu, perpustakaan tersebut harus memiliki koleksi, baik jumlah judul maupun jumlah eksemplarnya, yang mencukupi untuk mendukung pelaksanaan pendidikan, penelitian, dan pengabdian kepada masyarakat. ${ }^{9}$

Urgensi repositori di sebuah Perpustakan Perguruan Tinggi dapat dilihat dari fungsi dan pemanfaatannya. Repositori digunakan untuk menyimpan arsip digital dari sejumlah publikasi-publikasi ilmiah yang dihasilkan oleh Perguruan Tinggi tersebut, dan dapat diakses secara online dan dimanfaatkan oleh para akademisi untuk pengembangan ilmu pengetahuan. Pemanfaatan koleksi elektronik sudah menjadi tren di era digital seperti saat ini, dan sudah selayaknya semua karya hasil penelitian para akademisi diproduksi dan dikembangkan dalam bentuk elektronik

\footnotetext{
Menggunakan Eprints, Berkala Ilmu Perpustakaan dan Informasi, Vol. XI, No. 2, 2015, 50-61.

${ }^{8}$ Syihabuddin Qalyubi, Dasar-Dasar Ilmu Perpustakaan dan Informasi, Yogyakarta: Fakultas Adab UIN Sunan Kalijaga, 2007, 10.

${ }^{9}$ Perpustakaan Nasional Republik Indonesia. Undang-Undang Republik Indonesia Nomor 43 Tahun 2007 Tentang Perpustakaan Pasal 24 Ayat 2, http://dev.perpusnas.go.id/law/undang-undangnomor-43-tahun-2007-tentang-perpustakaan/, diakses tanggal 25 Oktober 2017.
} 
agar memudahkan masyarakat untuk mengaksesnya. Tujuan dibentuknya repositori adalah untuk memberikan akses terbuka kepada hasil-hasil penelitian Universitas, menciptakan visibilitas global bagi Universitas melalui riset ilmiah, mengumpulkan publikasi Universitas kedalam satu lokasi, serta menyimpan dan melestarikan aset (koleksi) digital. ${ }^{10}$

Pemanfaatan repsitori yang baik dapat meningkatkan sitasi dan peringkat webometric sebuah Perguruan Tinggi atau Universitas karena karya ilmiah yang dihasilkan dapat diakses dan dimanfaatkan oleh banyak orang dari seluruh penjuru dunia tanpa mengenal waktu dan tempat. Repositori perpustakaan disebuah Perguruan Tinggi juga menjadi kunci majunya sebuah lembaga karena, repositori memiliki fungsi untuk meningkatkan peringkat Webometrics dalam rangka mewujudkan World Class University. Oleh sebab itu, Universitas dan Perguruan Tinggi lainya berusaha keras untuk memperbaiki dan meningkatkan repositori yang dimilikinya. Perguruan tinggi yang tidak mampu menciptakan repositori yang baik tentunya akan sulit berkembang dan siap-siap untuk ditinggal peminatnya.

\section{Bentuk Penyerahan Tugas Akhir (Skripsi, Tesis, Disertasi) Mahasiswa}

Bentuk penyerahan karya akhir (skripsi, tesis, disertasi) mahasiswa UGM dilakukan melalui sistem unggah mandiri. Unggah mandiri merupakan salah satu sarat untuk wisuda, dan petugas perpustakaan pusat akan melakukan verifikasi data apabila format yang di-unggah telah sesuai dengan prosedur. Unggah mandiri ini sudah diberlakukan mulai tanggal 1 september 2014, dan berlaku untuk seluruh mahasiswa UGM. Unggah mandiri dapat diakses melalui https://unggah.etd.ugm.ac.id. Unggah mandiri bertujuan untuk memudahkan mahasiswa dalam menerbitkan hasil karya tulis dan hasil penelitiannya melalui sistem repositori Perguruan Tinggi. Disisi lain, manfaat atau keuntungan bagi Perguruan Tinggi atau Univeritas tentu bukan dalam finansial, tapi lebih kepada keuntungan reputasi. Semakin banyak penulis mensitir karya akademisi Universitas tertentu, maka Univeritas tersebut semakin diakui sebagai Universitas yang punya reputasi dalam

\footnotetext{
${ }^{10}$ Ulpah Andayani, Pengolahan Konten Repositori, 48.
} 
bidang pengetahuan tertentu. Reputasi yang baik akan membuat peringkat Universitas tersebut semakin naik dan akan diperhitungkan oleh masyarakat, dan para peneliti. Selain unggah mandiri, pada masing-masing perpustakaan fakultas juga memiliki kebijakan sendiri, misalnya mahasiswa S1 psikologi diwajibkan untuk menyerahkan abstrak dan intisari skripsi dalam bentuk hard copy, sedangkan untuk program S2 dan S3 masih menyerahkan hard copy full untuk tesis dan disertasi.

"Penyerahan skripsi sekarang tidak lagi dalam bentuk cetak, namun hanya mengunakan unggah mandiri, dan rangkuman skripsi dijilid untuk diserahkan ke perpustakaan sekaligus untuk meminta surat bebas pustaka". ${ }^{11}$

Hasil observasi peneliti dilapangan juga menunjukkan adanya koleksi abstrak dan intisari dalam bentuk hard copy yang disusun dan ditempatkan pada satu rak khusus, begitu pula dengan tesis dan disertasi juga terdapat intisari dan abstrak dalam bentuk hard copy. Setelah selesai melakukan unggah mandiri dan pengumpulan intisari skripsi yang telah di jilid, petugas perpustakaan memvalidasi dan mengeluarkan surat bebas pustaka untuk persayaratan pendaftaran wisuda bagi mahasiswa yang bersangkutan. Perpustakaan UGM saat ini tidak memberlakukan penyerahan tugas akhir skripsi dalam bentuk file CD dan cetak, namun sebagian mahasiswa berangapan sistem penyerahan skripsi masih seperti tahun-tahun sebelumnya (pengumpulan skripsi dalam bentuk cetak), dan perpustakaan menerimanya dengan alasan tertentu. Kebanyakan dari mahasiswa tersebut sebenarnya sudah melakukan unggah mandiri namun skripsi dalam bentuk $\mathrm{CD}$ dan cetak sudah terlanjur dibuat, dan daripada terbuang sia-sia mereka menyerahkan kepada perpustakaan namun juga tetap mengumpulkan intisari skripsi yang sudah dijilid.

"saya sebenarnya sudah melakukan unggah mandiri, namun skripsi sudah terlanjur saya jilid, dan ternyata perpustakaan hanya meminta intisari atau rangkuman skripsi saja". ${ }^{12}$

${ }^{11}$ SI (Mahasiswa), wawancara oleh peneliti, Universitas Gadjah Mada Yogyakarta, Tanggal 26 Oktober 2017.

${ }^{12}$ MA (Mahasiswa), wawancara oleh peneliti, Universitas Gadjah Mada Yogyakarta, Tanggal 26 Oktober 2017. 
Berdasarkan pernyataan mahasiswa tersebut, berarti kebijakan unggah mandiri belum sepenuhnya dipahami oleh mahasiswa. Perpustakaan sekiranya lebih aktif lagi dalam mempromosikan kebijakan unggah mandiri dan hanya menerima intisari skripsi dalam bentuk cetak. Sealain diumumkan kebijakan tersebut juga harus dibuatkan surat keputusan tertulis. Perpustakaan dapat men-unggah informasi tersebut kedalam website resmi perpustakaan atau mengirimkan informasi tersebut melalui e-mail.

\section{Metadata yang Di-input Kedalam Sistem Repositori}

Unggah mandiri dilakukan dengan memperhatikan prosedur pengisian data agar tidak terjadi kesalahan dan gagal unggah. Mahasiswa diharuskan untuk mengisi form unggah mandiri terlebih dahulu sebelum mengunggah file, yang meliputi nama, NIM, fakultas, jenjang, e-mail UGM, e-mail lain, nomor telepon, dan bulan wisuda. Kemudian memasukkan metadata yang meliputi judul, abstrak/intisari, abstract, pembimbing atau promotor, kata kunci, jenis karya akhir, dan tahun. Sedangkan file yang diunggah semua meliputi pendahuluan, table conten, isi per-bab sampai daftar pustaka. Bagian yang mengolah hasil unggah mndiri mahasiswa adalah bagian publikasi perpustakaan. Untuk dapat melakukan unggah mandiri harus menggunakan akun e-mail UGM yang telah terdaftar sesuai jenjang studi mahasiswa yang bersangkutan.

Karya akhir mahasiswa yang dapat di-unggah melalui halaman http://lib.ugm.ac.id/ind/ ?page_id=287 meliputi: fulltext, summary, naskah publikasi/ ringkasan, halaman judul dan pengesahan, abstrak dan abstract, daftar isi, bab pendahuluan, bab penutup kesimpulan, dan daftar pustaka. Apabila proses pengunggahan gagal atau ditolak maka sistem secara otomatis memberi pemberitahuan, dan mahasiswa akan ditunjukan pada bagian konten yang belum terisi untuk melengkapinya. Berikut contoh unggah mandiri yang gagal dan harus diulangi kembali: 


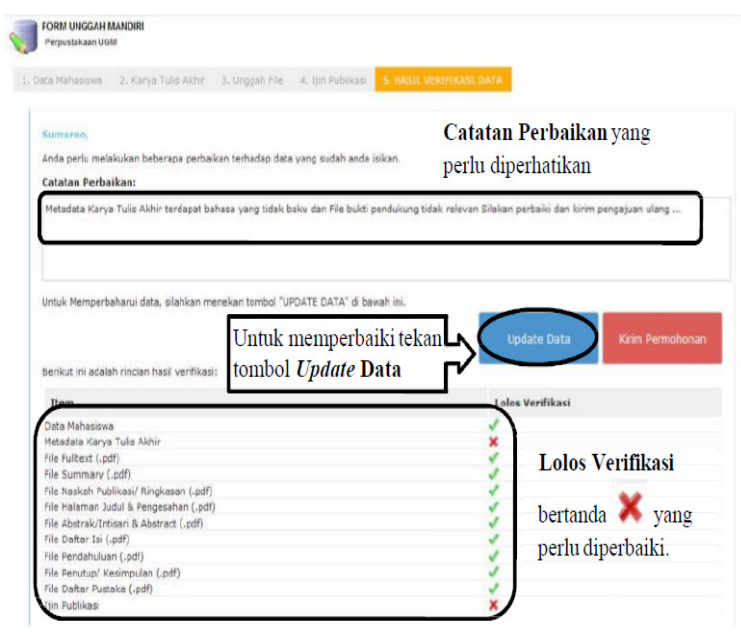

Gambar 1. Verifikasi Unggah Mandiri. ${ }^{13}$

Perpustakaan telah memberikan pedoman bagi mahasiswa agar tidak terjadi kesalahan input metadata dalam sistem unggah mandiri. Pedoman tersebut dapat di-download melalui website perpustakaan UGM (http://lib. ugm.ac.id/). Mahasiswa harus sabar dan teliti dalam memasukkan metadata tersebut, karena bisa jadi file tertukar. Untuk menghindari kejadian tersebut dibutuhkan verifikasi ulang oleh pustakawan, dan data tersebut harus benarbenar valid sebelum surat bebas pustaka dikeluarkan.

\section{Akses Repositori}

Kemudahan akses terhadap informasi merupakan merupakan nilai lebih untuk tetap menjaga eksistensi perpustakaan dimata masyarakat khususnya pemustaka. Salah satu informasi yang paling dibutuhkan oleh para akademisi khususnya mahasiswa di Perguruan Tinggi adalah akses terhadap hasil penelitian baik itu skripsi, tesis maupun disertasi melalui repositori. Karya akhir mahasiswa UGM yang telah diunggah secara mandiri dapat diakses oleh masyarakat secara umum, namun terdapat kebijakan dari

${ }^{13}$ Haryanta dan Dewi Nurhastuti. Panduan Bebas Pinjam Pustaka \& Unggah Mandiri Karya Tulis Akhir, http://lib.ugm.ac.id/data/panduan_unggah_mandiri_revisi2.pdf, diakses tanggal 25 Oktober 2017. 
perpustakaan untuk akses tersebut. Kebijakan pertama, mahasiswa dapat mengakses secara keseluruhan (full conten) melalui komputer yang disediakan perpustakaan pusat, yaitu di ruang ETD (Elektronik theses \& Disertation) atupun perpustakaan-perpustakaan fakultas. Artinya akses penuh terhadap konten hanya bisa dilakukan dengan mendatangi perpustakaan. Akses penuh yang dimaksud disini adalah mahasiswa diperkenankan untuk membaca di komputer ETD, namun file yang ditampilkan didalam komputer tersebut tidak dapat disalin (copy) kedalam flasdisk atau media penyimpana lainya.

"Apabila mengaksesnya melalui komputer perpustakaan konten yang dapat ditampilkan full (judul-daftar pustaka) namun tidak bisa dicopy". ${ }^{14}$

Kebijakan kedua, apabila pemustaka mengakses dari luar perpustakaan pusat dan perpustakaan fakultas, maka konten yang didapat hanya sebagian, meliputi abstract, bibliography, chapter 1 (introduction), chapter 5 (conclusion), table of conten, dan title, namun semua file tersebut dapat di-download dan disimpan. Pemustaka dapat mengakses konten tersebut dari mana saja dan kapan saja baik menggunakan komputer maupun gadget yang terkonesksi dengan internet. Berikut tampilan konten yang dapat diakses dari luar perpustakaan:

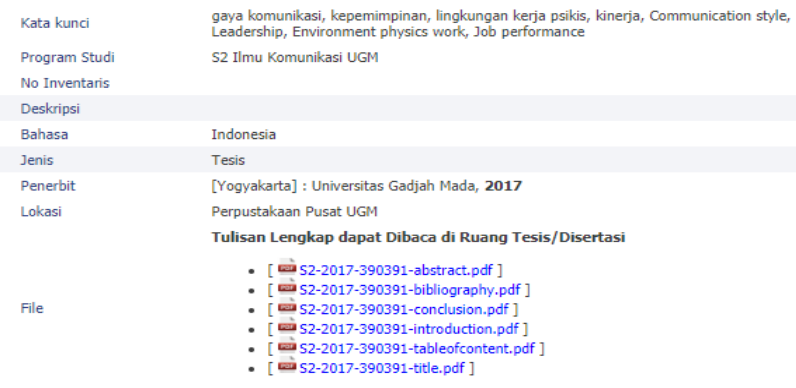

Gambar 2. Akses Repositori. ${ }^{15}$

\footnotetext{
${ }^{14} \mathrm{ANH}$ (Mahasiswa), wawancara oleh peneliti, Universitas Gadjah Mada Yogyakarta, Tanggal 26 Oktober 2017.

${ }^{15}$ ETD Repository UGM. http://etd.repository.ugm.ac.id/index.php?mod=book_detail\&su $\mathrm{b}=$ BookDetail\&act=view\&typ=htmlext\&buku_id=128123\&obyek_id=4\&unitid=\&jenis_id=, diakses tanggal 25 Oktober 2017.
} 
Keberadaan repositori di Perpustakaan Perguruan Tinggi sangat membantu civitas akademika untuk mempromosikan hasil-hasil penelitian yang telah dibuat begitu pula sangat bermanfaat sebagai bahan rujukan mahasiswa untuk menyelesaikan tugas-tugas kuliah maupun tugas akhir. Sisten repositori ini dapat meminimalisir adanya duplikasi karya ilmiah atau plagiarisme karena file yang telah di-unggah tersebar secara langsung dalam dunia maya sehingga harus disertai dengan ketentuan dan prosedur repositori yang jelas dari pihak perpustakaan.

\section{Persepsi pemustaka terhadap Sistem Unggah Mandiri Tugas Akhir dan Akses ETD Repositori}

Persepsi pada hakikatnya merupakan proses penilaian seseorang terhadap objek tertentu. Persepsi adalah pengalaman tentang objek, peristiwa atau hubungan-hubungan yang diperoleh dengan menyimpulkan informasi dan menafsirkan pesan. ${ }^{16}$ "Persepsi adalah suatu proses membuat penilaian atau pembangunan kesan mengenai berbagai macam hal yang terdapat di dalam lapangan penginderaan seseorang". Secara garis besar persepsi dapat dibagi menjadi dua, yaitu persepsi benda (objek stimulusnya merupakan suatu hal atau benda yang nyata dan dapat diindera secara langsung) dan persepsi sosial (terjadi karena kontak secara tidak langsung seperti melalui cerita atau apapun yang didengar melalui orang lain). ${ }^{17}$ Persepsi dapat diartikan sebagai suatu proses penerimaan terhadap suatu objek yang dirasakan melalui panca indera ataupun pengalaman seseorang sehingga dapat memberikan gambaran dan penilaian yang berarti terhadap objek tersebut.

Persepsi pemustaka terhadap perpustakaan dan pelayananya dapat dijadikan sebagai data dan pertimbangan penengelola perpustakaan untuk terus memperbaiki kualitas perpustakaan, termasuk juga dalam pengembangan repositori. Persepsi pemustaka terhadap sitem ungah mandiri dan akses ETD (Elektronik Theses \& Dissertations) di Perpustakaan UGM dapat dijelaskan sebagaimana berikut:

\footnotetext{
${ }^{16}$ Jalaluddin Rakhmat, Psikologi Komunikasi, Bandung: Remaja Rosdakarya, 2009, 5.

${ }^{17}$ Wiji Suwarno, Psikologi Perpustakaan, Jakarta: Sagung Seto, 2009, 52-53
} 
a) Sistem Unggah Mandiri dan ETD Merupakan Kebijakan yang Tepat Kebijakan unggah mandiri tugas akhir mahasiswa di Perpustakaan Perguruan Tinggi dimaksudkan untuk membangan sistem repositori yang kuat yang dampaknya pada berbaikan peringkat webomatriks Perguruan Tinggi. Oleh sebat itu, kebijakan ini diambil untuk menciptakan Perguruan Tinggi yang mampu bersaing di era global. Sebagian besar mahasiswa telah merasakan kemudahan dari kebijakan unggah mandiri ini, sebagaimana diungkapkan salah satu mahasiswa:

"Kebijakan unggah mandiri itu sangat tepat, karena penyerahan skripsi akan lebih mudah dan tidak harus datang ke perpustakaan". ${ }^{18}$

Kebijakan unggah mandiri saat ini dinilai sangat tepat karena fasilitas untuk mengakses informasi digital telah banyak dimiliki oleh sebagian besar masyarakat dari berbagai latar belakang, apalagi para akademisi yang setiap harinya bekerja dengan bantuan teknologi informasi. karya akhir (skripsi, tesis, dan disertasi) yang telah di-unggah secara mandiri dapat dilayankan kepada pemustaka melalui sistem ETD. ETD (Elektronik Theses \& Dissertations) saat ini sangat dibutuhkan bagi segenap sivitas akademika untuk memperoleh informasi dan rujukan dari hasil penelitian yang telah dilakukan oleh peneliti sebelumnya. Persepsi pemustaka terhadap kebijakan akses ETD sangat beragam. Sebagian mahasiswa berpendapat bahwa open acces itu perlu dan semua informasi yang terdapat dalam komputer diruang ETD boleh di-copy, namun sebagian yang lain menyatakan tidak perlu di-copy karena akan menimbulkan plagiarisme.

"Seharusnya skripsi di ETD boleh di-copy semua, jadi mahasiswa tidak perlu duduk lama di ruang tersebut dan dapat membacanya di rumah". ${ }^{19}$

"Semua file ETD tidak perlu di-copy, karena bisa terjadi plagiarisme". ${ }^{20}$ 26 Oktober 2017.

${ }^{18}$ SI (Mahasiswa), wawancara oleh peneliti, Universitas Gadjah Mada Yogyakarta, Tanggal

${ }^{19} \mathrm{MA}$ (Mahasiswa), wawancara oleh peneliti, Universitas Gadjah Mada Yogyakarta, Tanggal 26 Oktober 2017.

${ }^{20}$ SI (Mahasiswa), wawancara oleh peneliti, Universitas Gadjah Mada Yogyakarta, Tanggal 26 Oktober 2017. 
Perpustakaan telah meyediakan file digital melalui sistem unggah mandiri dan ETD dengan tujuan agar pemustaka dapat memanfaatkannya dengan baik, dan perpustakaaan harus memiliki kebijakan untuk open acces. Open acces wajib dilakukan perpustakaan di era keterbukaan informasi rangka mewujugkan pelayanan prima di perpustakaan. Kebijakan yang dicanangkan perpustkaan harus mempertimbangkan berbagai aspek agar tidak merugikan berbagai pihak. Kebijakan untuk tidak men-copy full paper di ruang ETD dan akses sebagian file skripsi melalui repositori sangat tepat dengan alasan untuk menghindari penyalahgunaan dokumen misalnya plagiarisme dan pelanggaran hak cipta.

b) Sistem Unggah Mandiri dan Akses ETD Repositori Dilihat dari Aspek Evektifitas dan Evisiensi

Istilah efektif paling umum diartikan sebagai hemat waktu, dan seringkali dikaitkan dengan istilah efisien yaitu hemat biaya. Sesuatu dapat dikatakan efektif dan efisian apabila memberikan manfaat. Berdasarkan hasil penelitian, mahasiswa dapat mengumpulkan tugas akhir (skripsi, tesis dan disertasi) dari mana saja dengan hanya meng-upload-nya kedalam sistem unggah mandiri. Selain itu mahasiswa dapat menghemat biaya untuk tugas akhir mereka, karena tidak perlu mencetak dan menjilidnya untuk diserahkan ke perpustakaan.

"Saya tidak perlu keluar uang banyak untuk menjilid skripsi kerena sekarang cuma diunggah melaui sistem dan dapat dilakukan kapan saja sebelum batas akhir pengumpulan". ${ }^{21}$

Sistem unggah mandiri di Perpustakaan UGM dapat dikatakan evektif karena dapat mempersingkat waktu mahasiswa dalam penyerahan tugas akhir mereka. Selain itu, dengan sistem unggah mandiri mahasiswa tidak perlu mengantri diperpustakaan hanya untuk mengumpulkan tugas akhir mereka. Mengantri di perpustakaan dapat menimbulkan masalah karena perpustakan akan menjadi sesak, ramai, dan dapat menggagu pemustaka lain untuk mendapatkan layanan informasi. Kecepatan dan

${ }^{21} \mathrm{ANH}$ (Mahasiswa), wawancara oleh peneliti, Universitas Gadjah Mada Yogyakarta, Tanggal 26 Oktober 2017. 
ketepatan akses terhadap informasi menjadi kebutuhan masyarakat saat ini, dan sistem ETD repostori ini dibangunya untuk menjawab tantangan tersebut. Akses ETD repositori dapat dikatakan evektif dan efisien karena dapat dilakukan dari mana saja dan kapan saja, meskipun akses yang diberikan perpustakaan hanya sebagian (tidak full), namun setidaknya dapat memberikan gambaran informasi yang dibutuhkan pemustaka.

c) Sistem Unggah Mandiri dan Akses ETD Repositori Dilihat dari Aspek Keamanan dan Kenyamanan

Keamanan dan kenyamanan merupakan faktor penting yang dapat mempengaruhi kepuasan pengguna aplikasi/sistem. Selain kecepatan sistem unggah mandiri juga memberikan dan kenyamanan bagi mahasiswa, karena penyerahan tugas akhir skripsi dapat dilakukan dari mana saja. Selain itu, data tugas akhir yang telah diunggah dapat dijadikan sebagai backup, artinya apabila file yang dimiliki sewaktu-waktu hilang maka mahasiswa dapat men-download-nya kembali melalui repositori perpustakaan. Sistem unggah mandiri ini sangat memberikan manfaat bagi mahasiswa yang tinggal jauh dari kampus karena mereka dapat melakukan unggah mandiri dari tempat tinggal mereka.

"Karena telah saya upload, saya tidak kawatir kalau file skripsi saya hilang. Ketika saya butuh tinggal download atau minta ke perpustakaan".22

Akses ETD repositori yang diberikan perpustakaan juga memberikan kemudahan dan kenyamanan bagi pemustaka untuk mencari informasi sesuai dengan kebutuhannya dengan cepat, tepat dan akurat. Pencarian informasi saat ini akan lebih mudah dengan bantuan aplikasi seperti ETD repositori dibanding harus mencari informasi pada tumpukan buku-buku cetak. Disamping itu, tren membaca masyarakat sekarang dan fasilitas yang diberikan perpustakaan menjadi faktor penting yang mempengaruhi pemustaka untuk lebih memilih koleksi elektronik dibanding cetak, karena kemudahan akses yang diberikan.

${ }^{22}$ SI (Mahasiswa), wawancara oleh peneliti, Universitas Gadjah Mada Yogyakarta, Tanggal 26 Oktober 2017. 


\section{Kesimpulan}

Sistem repositori memiliki peran penting bagi perpustakaan dan Perguruan Tinggi. Selain untuk menyimpan karya ilmiah yang dihasilkan oleh mahasiswa maupun para peneliti di Perguruan Tinggi, informasi yang terdapat didalam repositori juga dapat diakses secara online dan dimanfaatkan oleh para akademisi untuk pengembangan ilmu pengetahuan. Repositori juga memiliki fungsi untuk meningkatkan peringkat Webometrics dalam rangka mewujudkan World Class University. Persepsi pemustaka terhadap kebijakan unggah mandiri dan akses ETD repositori dinilai sangat tepat mengingat kebutuhan terhadap informasi elektronik saat ini semakin meningkat. Kebijakan tersebut wajib dilakukan untuk menciptakan open acces dalam rangka mewujudkan pelayanan prima di perpustakaan. Sistem unggah mandiri dan akses ETD repositori dapat meningkatkan evektifitas dan efisiensi karena mahasiswa dapat men-unggah dan mengakses tugas akhir mereka dari mana saja dan kapan saja. Selain itu juga memberikan keamanan dan kenyamanan bagi mahasiswa karena file yang telah diungah tersimpan didalam sistem dan dapat di-download atau diminta ke perpustakaan ketika sewaktu-waktu dibutuhkan.

\section{Daftar Pustaka}

Rahayuningsih, F. Pengelolaan Perpustakaan. Yogyakarta: Graha Ilmu. 2007. Pendit, P. Laxman, Perpustakaan Digital dari A sampai Z. Jakarta: Citra Karyakarsa Mandiri. 2008.

Qalyubi, Syihabuddin. Dasar-Dasar Ilmu Perpustakaan dan Informasi. Yogyakarta: Fakultas Adab UIN Sunan Kalijaga. 2007.

Rakhmat, Jalaluddin. Psikologi Komunikasi. Bandung: Remaja Rosdakarya. 2009.

Suwarno, Wiji. Psikologi Perpustakaan. Jakarta: Sagung Seto. 2009.

\section{Web dan Jurnal}

Andayani, Ulpah, Pengolahan Konten Repositori di Pusat Perpustakaan UIN 
Syarif Hidayatullah Jakarta, Jurnal Al-Maktabah, Vol. 14, 2015, 46-55.

ETD Repository UGM, http://etd.repository.ugm.ac.id/index. php?mod=book_detail\&sub=BookDetail\&act=view\&typ=htmlext \&buku_id=128123\&obyek_id=4\&unitid=\&jenis_id=, diakses tanggal 25 Oktober 2017.

Haryanta dan Nurhastuti, Dewi. Panduan Bebas Pinjam Pustaka \& Unggah Mandiri Karya Tulis Akhir, http://lib.ugm.ac.id/data/panduan_ unggah_mandiri_revisi2.pdf, diakses tanggal 25 Oktober 2017.

Perpustakaan Nasional Republik Indonesia. Undang-Undang Nomor 43 Tahun 2007 Tentang Perpustakaan. http://dev.perpusnas.go.id/law/ undang-undang-nomor-43-tahun-2007-tentang-perpustakaan/, diakses tanggal 25 Oktober 2017.

Perpustakaan UGM. Unggah Mandiri UGM. https://unggah.etd.ugm.ac.id diakses tanggal 25 Oktober 2017.

Rodliyah, Ummi. Penggunaan Aplikasi E-Prints untuk Pengembangan Intitutional Repository dan Pengaruhnya terhadap Peringkat Webometrics Perguruan Tinggi di Indonesia, Libraria, Vol. 4, No. 1, Juni 2017, 223-248.

Wiyarsih, Pemanfaatan Koleksi Repository Perpustakaan Fakultas MIPA UGM Menggunakan Eprints, Berkala Ilmu Perpustakaan dan Informasi, Vol. XI, No. 2, 2015, 50-61.

Wawancara

ANH (Mahasiswa), wawancara oleh peneliti, Universitas Gadjah Mada Yogyakarta, Tanggal 26 Oktober 2017.

MA (Mahasiswa), wawancara oleh peneliti, Universitas Gadjah Mada Yogyakarta, Tanggal 26 Oktober 2017.

SI (Mahasiswa), wawancara oleh peneliti, Universitas Gadjah Mada Yogyakarta, Tanggal 26 Oktober 2017. 